\title{
Dictynna
}

Dictynna

Revue de poétique latine

$3 \mid 2006$

Varia

\section{Venus, Varro and the vates: toward the limits of etymologizing interpretation}

\section{Stephen Hinds}

\section{(2) OpenEdition \\ 1 Journals}

\section{Electronic version}

URL: http://journals.openedition.org/dictynna/206

DOI: 10.4000/dictynna.206

ISSN: 1765-3142

\section{Electronic reference}

Stephen Hinds, "Venus, Varro and the vates: toward the limits of etymologizing interpretation », Dictynna [Online], 3 | 2006, Online since 12 October 2010, connection on 11 September 2020. URL : http://journals.openedition.org/dictynna/206 ; DOI : https://doi.org/10.4000/dictynna.206

This text was automatically generated on 11 September 2020 .

\section{(c) (i) (2) $\Theta$}

Les contenus des la revue Dictynna sont mis à disposition selon les termes de la Licence Creative Commons Attribution - Pas d'Utilisation Commerciale - Pas de Modification 4.0 International. 


\title{
Venus, Varro and the vates: toward the limits of etymologizing interpretation
}

\author{
Stephen Hinds
}

\section{Preface}

1 This paper began life a long time ago as a kind of response to Robert Maltby's Lexicon of Ancient Latin Etymologies (Leeds 1991); it took shape on the conference circuit at the same time that James J.O'Hara's True Names: Vergil and the Alexandrian Tradition of Etymological Wordplay (Ann Arbor 1996) was nearing completion. ${ }^{1}$ It had an even more remote reference point in a working out of some unresolved feelings about Frederick Ahl's Metaformations: Soundplay and Wordplay in Ovid and Other Classical Poets (Ithaca 1985). A combination of new department chairing and new parenthood caused the paper to miss its appointment with a publisher back in 1998. It then sank into the dormancy from which I am here rescuing it, encouraged on the one hand by a number of friends and colleagues who have read and commented on privately-circulated copies over the years, and on the other by the hoped-for hospitality of an electronic journal to work of a slightly irregular kind. It may now appear just in time to mark the next major event in Latin etymologizing interpretation: John Henderson's Isidore's Creation: Truth from Words (Cambridge) will be published soon. Although I have updated individual references where appropriate, I have not tried to recast the argument in any major way, nor to offer full bibliographical back-up for every passing generalization: the paper is intentionally presented as what it is, a lightly annotated lecture and a mid-1990s period-piece. 


\section{Venus at play ${ }^{2}$}

\section{Bondage in Propertius 3}

2 In medias res. The following couplet sets us down in the middle of a closing sequence of poems in Propertius 3, in which the poet is saying a long goodbye to elegiac love (3.24.13-14):

correptus saevo Veneris torrebar aeno;

vinctus eram versas in mea terga manus

Venus seized me and roasted me in her cruel cauldron: I was a prisoner with hands

bound behind my back.

3 Consider here, not the striking and hard to parallel image in the hexameter (apparently a Venusian equivalent of the Bull of Phalaris), but the wholly familiar image in the pentameter - which can either be read as completing the vignette in the hexameter or as adding another. The bondage of love: it is a common metaphor. In fact it is hardly a metaphor at all. From one point of view, which I can highlight typographically,

correptus saevo Veneris torrebar aeno;

vinctus eram versas in mea terga manus

the bondage of love is a quite literal statement of the agency of Venus. Let the lateRepublican polymath and grammarian Varro explain, in a passage of his De Lingua Latina which describes how heat and moisture are embodied, respectively, in the male and the female reproductive forces ( $L L$ 5.61-2):

... et mas ignis, quod ibi semen, aqua femina, quod fetus ab eius humore, et horum vinctionis vis Venus. Hinc comicus: "huic victrix Venus, videsne haec?" Non quod

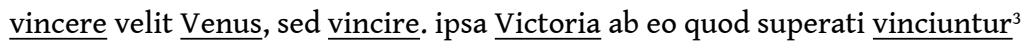

... and fire is male, which the semen is in the other case, and water is female, because the embryo develops from her moisture, and the force that brings their vinctio "binding" is Venus "Love'. Hence the comic poet says, "huic Venus victrix ..." not because Venus wishes (or signifies) vincere "to conquer", but vincire "to bind'. Victory herself is named from the fact that the overpowered vinciuntur "are bound'.

In a footnote here, the Loeb editor Roland Kent, on behalf of mid $20^{\text {th }}$ century classical linguistics, offers a brisk reprimand to Varro for the high-handedness of these etymological explanations: ${ }^{4}$

'Apparently Venus is said to be the basis of the word vinctio; wrong.'

No meeting of minds across the millennia here, evidently. But Varro's words make a good deal of sense in a Roman poetic context. Consider Propertius again, four poems earlier in Book 3, resolving to take the time to negotiate a kind of lovers" contract before going to bed with his girl (3.20.19-23):

quam multae ante meis cedent sermonibus horae,

dulcia quam nobis concitet arma Venus!

namque ubi non certo vincitur foedere lectus, non habet ultores nox vigilanda deos,

et, quibus imposuit, solvit mox vincla libido

How many hours shall first give way to my discussion before Venus spurs us to her sweet warfare! For when a union is not bound (vincitur) by fixed terms, the lover's sleepless nights have no gods to avenge them, and passion soon loosens the fetters (vincla) of those whom it has bound.

6 With just a little more effort than in the other Propertian passage, we can locate a Venus/vincire etymology here too: Venus as the "binder" of the amorous couple, a binding that will not last if it is done carelessly. The sequence of thought in this elegy is 
not easy, and many editors have found the transition between 19-20 and 21-2 an unacceptably abrupt one. ${ }^{5}$ They may be right - or they may be underestimating the cohesiveness of the argument through a failure to recognize its underlying etymological logic.

Let me complicate things a little by adding to my etymological anthology another passage from earlier in the same Propertian book (3.5.21-2):

me iuvat et multo mentem vincireLyaeo,

et caput in verna semper habere rosa

It is my delight also to bind (vincire) my mind with deep draughts of Lyaeus ['The

one who sets free'] and ever to have my head garlanded with the roses of spring.

The wine-god Lyaeus, instead of "loosening" the mind, in accordance with the meaning of his Greek cult-title, paradoxically "binds" it: a classic instance of etymological play kat" antiphrasin. ${ }^{6}$ Remarkably, this is the second instance within the same poem of a name-play based upon the principle of opposite meaning: compare lines 7-8, featuring a "Prometheus" who acts without "forethought':

o prima infelix fingenti terra Prometheo!

ille parum cauti pectoris egit opus

O primal clay, so ill-starred for Prometheus" fashioning hand! He did the job of a

mind too imprudent (parum cauti).

What we have in 3.5.21-2, then, is an apparent case of etymological subversion, where the implicit etymology seems to subvert the explicit statement: the poet's (explicit) delight is in binding the mind; but the (implicit) etymology makes the binding into an unbinding. However, the blank contradiction is easily converted on closer inspection into meaningful paradox. (Let me offer three observations here, the third of which will bring us back to Venus:)

(1) The phrase vincire Lyaeo can be argued to explore or mediate a tension between entanglement and liberation (a) in the physiology of drinking and (b) in the workings of Dionysiac possession.

(2) vincire Lyaeo acquires resonance when it is read as a transformation of the passage's likely model in Horace's Odes (Hor. Carm. 1.7.22-3), ${ }^{7}$

$$
\text { ... tamen uda Lyaeo }
$$

tempora populea fertur vinxisse corona

.... [Teucer] is yet said to have bound (vinxisse) garlands of poplar about his brows

liquid with Lyaeus

- a transformation which packs a typically Propertian brachylogy of thought and expression. In Horace, a literal garland binds the brows (i.e. the tempora envisaged externally), while Lyaeus etymologically unbinds (and irrigates) the mind (i.e the tempora envisaged internally). In Propertius" imitation the two elements in the compound Horatian utterance are fused - with an accompanying sharpening of the paradox ('to bind the mind with the Unbinder'). A garland shows up separately and overtly in Propertius" pentameter - almost like a gloss for the buried Horatian logic of vincire in the hexameter.

(3) Who would with greater etymological appropriateness "bind" the mind? I quote Propertius 3.5.21-2 again, this time with more surrounding context. The elegist, in a familiar topos, is contrasting the youth which he spends in activities associated with love and love poetry with the old age which he will spend on natural philosophy (Prop. 3.5.19-25):

me iuvat in prima coluisse Helicona iuventa

Musarumque choris implicuisse manus; 
me iuvat et multo mentem vincireLyaeo,

et caput in verna semper habere rosa.

atque ubi iam Venerem gravis interceperit aetas,

sparserit et nigras alba senecta comas,

tum mihi naturae libeat perdiscere mores

It is my delight to have worshipped Helicon in my early youth and joined hands in

the Muses" dance; it is my delight also to bind (vincire) my mind with deep draughts

of Lyaeus and ever to have my head garlanded with the roses of spring. And when

the weight of advancing years has cut off the games of Venus, and white old age has speckled my black locks, then let my fancy turn to exploring the ways of nature.

The paradox of vincire Lyaeo in line 21 can now be read as encompassing a precise etymological substitution. Who would with greater etymological appropriateness be said to "bind", vincire, the mind? Venus, of course, as we have seen in our other Propertian passages; and, sure enough, that goddess, arriving in the very next hexameter (line 23, with my emphasis), retrospectively opens up an etymological dialogue between Lyaeus in line 21 and this more etymologically obvious "binder" in line 23 (Venus/vincire). Gods of wine and gods of love are often complicit in the world of love poetry (cf. Prop. 1.3.14 hac Amor hac Liber, durus uterque deus); here their complicity gains an extra edge from an etymologizing presentation which plays with the status of the "Unbinder" and the "Binder" as opposite forces.

11 In the point just made, my reading of Lyaeus as an etymological "substitute" for Venus in line 21 is authorized by the explicit naming of Venus in line 23. But arguably, this elegy (whose very theme is the association of the pursuit of love with other, cognate life-choices) has already invoked the name of Venus right back in its opening verse (3.5.1), through another such "cletic obliquity" (a term which I invent now, and will pick up in my third section):

pacis Amor deus est, pacem veneramur amantes

Peace has Love for its god, we lovers venerate (veneramur) peace

How many Love-Gods are present here in the opening verse of Propertius 3.5? A normal paraphrase of the line would run thus: "We lovers venerate peace as we venerate the god Amor'; but an etymologizing paraphrase might offer the following supplement: "We lovers venerate peace as we venerate... the goddess Venus." That is what an etymologizing reading finds in the verb venerari - and it may be significant that Propertius 3.4, with which 3.5 forms a clear pair (arma deus Caesar... / pacis Amor deus...), ends with an explicit prayer to Venus in its penultimate couplet (19-20). One will search in vain in ancient grammatical discussions to find such a connexion between Venus and venerari spelled out directly. ${ }^{8}$ But, as it happens, this is the etymological approach to Venus favoured by modern philologists - and we shall find another Roman elegist apparently playing with it too in my next sequence of case studies, ahead in [Tibullus] 3.8. Not just Venusian bondage, then, but Venusian veneration too.

13 My opening set of case-studies has grouped four explorations of an etymologizing link between Venus and vincire. Does that mean that I have come up with a single key to all these four passages? I don't think so. It might seem obvious, say, to treat my Varronian passage (LL 5.61-2) as the cipher which allows us to decode the word-plays in Propertius 3.24, 3.20 and 3.5. However, even if we accept the prior (and unwarranted) assumption that it is for the grammarian, Varro, to state the linguistic rules and for the love-poet, Propertius, to follow them, it is still clear that Propertius" three versions of the Venus/ 
vincire etymology do not so much reproduce Varro's patterns of explanation as rather usurp them - in three different ways.

Or consider the matter in terms of my own starting-point, the couplet from Propertius 3.24. In this poem and its successor, 3.25, which ends Propertius" third book, the poet renounces his long years of subjection to a cruel mistress, a subjection bitterly characterized through the language of the slavery of love. Here is the local interpretation for our etymology: as the poet complains in lines 13-14 of being tortured and "bound", the Venus/vincire etymology clearly functions in context to define Venus herself as the agent and enforcer of servitium amoris. But does that mean that the 3.24 passage allows us to "read off" the Venus/vincire etymology in just the same way in the other Propertian passages discussed? Evidently not. Just four poems earlier, as we have seen, the same poet has already used Venus/vincire differently, and rather more benignly, to negotiate between the "binding" of a lovers" embrace and the mutual and quasi-legalistic "binding" of a lovers" contract (3.20.19-23); and still earlier in Book 3 he has associated it, albeit obliquely, with the pleasant kind of "binding" with which a draught of alcohol constrains the mind (3.5.21-2 with 23). As for Varro, his version of Venus/vincire involves something different from all of these, viz the cosmic and physiological "binding" of heat and moisture in the universe in general, and in sexual intercourse in particular.

Therefore, rather than using these parallels (as I may have seemed to do before) to authorize an unproblematic "reading off" of the etymological play in all the various passages, I should perhaps rather use them to dramatize the excess of interpretative possibility immanent in any one of them. The etymology which is available to explain the violent (and non-mutual) bondage of servitium amoris is also available to evoke other, different and less bleak images of erotic binding too - images of legal mutuality and reciprocity, images of wine-induced befuddlement, images of fusion in physics and physiology,... probably others besides. In the couplet with which I began, 3.24.13-14, Propertius may be choosing to suppress the traces of these other associations in order to fit the Venus/vincire etymology smoothly to one particular, local vignette; at a narrow level of intentionality he may be unaware, and many of us as readers may be unaware, that any such suppression is going on. On the other hand, the fact that different ways of construing theVenus/vincire etymology are offered elsewhere within Propertius 3 itself does seem to imply some authorial self-knowledge in this matter. Thus, we might read into the Propertius 3.20 and 3.24 passages a calculated transformation of Venus/vincire from positively charged etymology in 3.20 to negatively charged etymology in 3.24, with "Venus the binder" forced into a perversion of her earlier sense in an encapsulation of the poet's closural attempt to bid farewell to the lover's discourse at the end of the third book. ${ }^{9}$ In any case, however much it be with the author's volition, or however much in the author's despite, one lesson of our opening set of case-studies would seem to be that etymological word-plays can unfix poetic meaning just as effectively as they can fix it. I leave that thought there, and move on to my second set of case-studies.

\section{Epiphany in Sulpicia}

Modern critics of Latin poetry who immerse themselves in the etymological thinking of the Romans inhabit a kind of twilight zone - but a twilight zone which became increasingly populated in the course of the 1980s and 1990s. In fact it acquired in those 
years its own Baedeker Guide, putting it for the first time within reach of the casual philological tourist: Robert Maltby's 1991 Lexicon of Ancient Latin Etymologies. Both the highways and the by-ways are now much more crowded than they were. Virgil's Aeneid and Ovid's Metamorphoses have each attracted contrasting pairs of book-length studies; ${ }^{10}$ and, within elegy, the poetry of Tibullus has emerged as a major proving-ground for taxonomies of etymological word-play, most notably in 1990s articles by Maltby and by Francis Cairns. ${ }^{11}$ These last-mentioned works stop just short of the bits of the Corpus Tibullianum not by Tibullus; and that is where my own Rough Guide is headed next.

Here is the beginning of the sequence of elegies by Sulpicia, ${ }^{12}$ with my emphases signalling a possible etymology in line 1 ([Tibullus] 3.13.1-5):

tandem venit amor, qualem texisse pudori quam nudasse alicui sit mihi fama magis.

exorata meis illum Cytherea Camenis attulit in nostrum deposuitque sinum. exsolvit promissa Venus...

At last has come (venit) a love such that the rumour of having concealed it would shame me more than that of having disclosed it to someone. Won over by my Muse's prayers, Cythera's queen has brought and placed him in my arms. What Venus promised she has fulfilled...

In book 2 of Cicero's De Natura Deorum, Lucilius Balbus, representing the Stoic view, includes in a catalogue of etymologies the derivation of Venus from venire (2.69):

quae autem dea ad res omnes veniretVenerem nostri nominaverunt, atque ex ea potius venustas quam Venus ex venustate

Venus was so named by our countrymen as the goddess who veniret "makes an advent" to all things; her name is not derived from the word venustas (beauty) but rather venustas from it.

His interlocutor Cotta, representing the Academy, scoffs at such etymologizing in the following book of the same work (3.62):

in enodandis autem nominibus quod miserandum sit laboratis: "Saturnus quia se saturat annis, Mavors quia magna vertit, Minerva quia minuit aut quia minatur, Venus quia venit ad omnia, Ceres a gerendo." quam periculosa consuetudo; in multis enim nominibus haerebitis: quid Veiovi facies, quid Volcano?

But as for your strained etymologies, one can only pity your misplaced ingenuity! Saturnus is so called because he is "sated with years", Mavors because he "subverts the great", Minerva because she "minishes", or because she is "minatory", Venus because she venit "makes an advent" to all things, Ceres from gero "to bear'. What a dangerous practice! with a great many names you will be in difficulties. What will you make of Vejovis, or Vulcan?

Each speaker can teach us something about ancient etymologizing. Balbus teaches us that etymologies may not be isolated effects, but may function within larger, integrated belief-systems (here, Stoic ways of rationalizing or comprehending the divine); we shall come back to this perspective in my third section. Cotta's scorn serves as a useful reminder that just because a particular etymology or system of etymologies is attested from antiquity, even from approximately the "right" time and place within antiquity, we should not regard it therefore as uncontestable evidence for what "all Romans", viewed somehow monolithically, believed. What the debate in De Natura Deorumdoes show, however, is precisely that the debate and contestation of etymologizing interpretation is an important activity for many Romans - it was to Cicero, remember, the author of De Natura Deorum, that Varro dedicated his De Lingua Latina -; and, of 
course, in the act of rejecting the Venus/venire etymology, Cotta has reiterated it: like it or not, the etymology is evidently "out there" as an available thought about Venus.

Back, then, to Sulpicia. Tandem venit amor: the phrase is multiply resonant: the onset of an emotion, the arrival of a specific young man, but also (even, perhaps, before it is "glossed" by the names in lines 3 and 5), the epiphany of a goddess, who presides over the emotion and provides the young man - a goddess, in short, who finally (tandem) fulfils the promise implicit in her name (Venus venit).

The Sulpician juxtaposition is not hard to parallel. ${ }^{13}$ Here is Ovid, introducing the month of Venus (Aprilis<Aphrodite, incidentally) in the proem to Fasti 4 (lines 13-14):

venimus ad quartum, quo tu celeberrima mense:

et vatem et mensem scis, Venus, esse tuos

We have come (venimus) to the fourth month in which you are honoured above all

others: you know, Venus, that both the poet and the month are yours.

Here too is Ovid's personified figure of Elegy, giving herself a job-description even more thoroughly Venusian than it appears at first glance (Amores 3.1.43-4):

rustica sit sine me lascivi mater Amoris:

huic ego proveni lena comesque deae

The mother of sportive Love, without me, would be a bumpkin: as procuress and comrade to this goddess did I come forth (proveni)

The orthodox rendition of proveni here is 'I arose, I came forth as'; but in the present context another nuance in the verb (unmentioned, of course, by the lexicographers) is hard to resist: provenire, "to act in the interests of, or as the representative of, Venus (pro Venere).'

The discussion in De Natura Deorum associates the Venus/venire etymology with the Stoics; but Lucretius is not immune to its charms (DRN 1.1-2, 6-7):

Aeneadum genetrix, hominum divomque voluptas,

alma Venus...

te, dea, te fugiunt venti, te nubila caeli

adventumque tuum...

Mother of Aeneas and his race, pleasure of men and gods, nurturing Venus...

From you, O goddess, from you the winds flee away, the clouds of heaven from you and your advent (adventum)...

It has been suggested by J.-M. Snyder, indeed (in a 1980 book written against the background of Friedländer's seminal article on Lucretian word-play), that the whole opening section of De Rerum Natura can be read as an exploration of Venus as the one who venit ad omnia..$^{14}$ However, at least one other etymological approach to Venus seems to be discernible elsewhere in the Lucretian proem - so we might perhaps better envisage the Lucretian opening as an exploration of different etymological aspects of the goddess (an incipient etymological aretalogy, if you like ${ }^{15}$ ). Venus who venit ad omnia; but also Venus as goddess of vis (DRN 1.12-13):

aeriae primum volucres te, diva, tuumque

significant initum perculsae corda tua vi

First the fowls of the air proclaim you, divine one, and your approach, pierced to the heart by your force (tua vi).

The latter etymology has been argued to be in play later in De Rerum Natura, at any rate, when Venus is up for discussion in less favourable circumstances (DRN 4.1113-14): ${ }^{16}$ 
usque adeo cupide in Veneris compagibus haerent,

membra voluptatis dum vi labefacta liquescunt

So eagerly do they cling in the couplings of Venus, while their limbs slacken and melt under the force (vi) of delight. incipit-poem, not this time Sulpicia's but that of her attentive reader the amicus Sulpiciae, author of the group of poems which, though positioned before it in the Corpus, seems to function as a sequel and response to Sulpicia's own (or "own') set ([Tib.] 3.8.1-12): ${ }^{19}$

Sulpicia est tibi culta tuis, Mars magne, kalendis: spectatum e caelo, si sapis, ipse veni.

hoc Venusignoscet: at tu, violente, caveto ne tibi miranti turpiter arma cadant.

illius ex oculis, cum vult exurere divos, accendit geminas lampadas acer Amor.

illam, quidquid agit, quoquo vestigia movit, componit furtim subsequiturque Decor.

seu solvit crines, fusis decet esse capillis; seu compsit, comptis est veneranda comis.

urit, seu Tyria voluit procedere palla; urit, seu nivea candida veste venit

Great Mars, it is your Kalends, and Sulpicia is dressed for you. Come yourself (ipse veni), if you have wit, from heaven to see her. Venus will pardon this; but you, violent one (violente), have a care lest to your shame your weapons drop as you marvel. From her eyes, when he wants to burn up the gods, does fierce Love kindle his twin torches. Whatsoever she does, whithersoever she turns her steps, Grace follows her unseen to order all aright. Has she loosed her hair? Then flowing locks become her. Has she dressed it? With dressed hair she is worthy of veneration (est veneranda). She fires the heart if she chooses to appear in gown of Tyrian hue; she fires it if she comes (venit) in the sheen of snowy robes.

In the third line, Venus will have two things to pardon. First, Mars will be giving to Sulpicia the attention that he might be expected to give to Venus herself, as his divine partner in love. Sulpicia's consequent prominence is punningly reflected in the tribute to her hair in line 10: est veneranda: "she is to be venerated... sc. like Venus'. (For Venus/ venerari cf. Propertius 3.5.1 earlier.) And in line 12 Sulpicia continues to supplant Venus by attracting Venusian vocabulary: venit "she comes... sc. like Venus'.

But Venus is supplanted in another way too. It is she, the goddess of love, rather than the war-god Mars, who might expect by the laws of generic propriety to preside over the beginning of a collection of erotic elegies - especially the beginning of a collection of Sulpician elegies: compare Sulpicia's own incipit-poem at [Tib.] 3.13.1-5, just discussed. And again this conceit, whereby Mars usurps the rightful generic place of Venus, is underscored by Venusian etymologizing. In line 2, instead of summoning Venus with her "cletic imperative" veni, the poet uses the imperative to summon Mars: ipse veni..$^{20}$ In lines 3-4, instead of invoking the erotic vis of Venus, the poet invokes - and belittles $^{21}$ - the (cognate) violentia of Mars. ${ }^{22}$ 
venerari, venire, violentus: one further etymologizing nuance remains. According to authorities cited in Servius, Venus is so called because of the venia "indulgence" that she bestows (Serv. Aen. 1.720):

Venerem vocari quidam propter promptam veniam dicunt

According to some Venus gets her name from her ready indulgence (venia).

May not this offer a key to the first half of line 3? hoc Venus ignoscet: in other words, Venus dabit veniam? Sulpicia had begun her elegiac set with a single etymological play (venit) on the name of Venus; her successor the amicus has complicated the original play and added three more of his own: a small glimpse, perhaps, of the kind of emulation between etymologizing poets which Jim O'Hara traced, as between Ovid and Virgil, in a notable 1996 parergon to his True Names. ${ }^{23}$

The reader may be sensing a crisis of interpretability. Let me pose some questions on behalf of the sceptic. How can one possibly argue for an etymological play in the verb venire in passages like this, given that the most natural verb with which any god, man or beast makes an advent anywhere is venire? And, as one reviews a number of the examples in my paper thus far, what warrant is there to take the omnipresent poetic habit of assonantal and alliterative paronomasia, and to read into it a series of abstruse etymological word-plays? How does one determine where to draw the line between etymological word-play and mere paronomasia?

Lucretius, for example, is notoriously promiscuous in matters of assonance and alliteration: in his proem passage quoted above, if Venus... adventum (DRN 1.2, 7) is to be seen as etymologically significant, what of the close proximity of the venti ('winds') in line 6, for which (in the absence of any parallel from the ancient grammarians) Snyder's monograph seems to claim no etymological significance, treating it rather as an inert assonantal "link" between two etymologically charged terms in lines 2 and $7 ?^{24}$ Why, finally, should we suppose that elegiac love poets are interested in pursuing the etymological debates of grammatical treatises at all? These questions will be pursued a little farther in the sections which follow.

\section{Varro at the point of evanescence}

How do we decide when paronomasia is and when it is not etymologically motivated? The problem has of course been discussed before, most notably perhaps by Robert Maltby in "The limits of etymologising" in Aevum Antiquum for 1993. I should like to offer a supplement to the series of heuristic questions which Maltby asks at the beginning of that important discussion. What should we do, he asks there, about the Latin poets of all genres and periods who may engage in paronomasia without etymological intent? and also what are we to do about an even more shifty character, the ancient writer of glosses on the early poet, who may read etymological links into his verse source's paronomasia where no such links were intended? But Maltby's is an article about distinctions between etymological and paronomasial intent in the language of poets; and what does not come up there (nor in Francis Cairns's later taxonomy of etymologies and etymological "markers" in PCPS for 1996) is any problematization of the distinction between etymological and paronomasial intent in the language of the etymologizing grammarians themselves. The role of (say) Varro in De Lingua Latina, as far as most modern critics of Latin poetry are concerned, is to furnish explicit etymologies of words, in terms of which the poet's implicit etymological word-plays can be measured, 
for good or for ill: but what is missing in this eminently sensible deployment of Varro is an acknowledgement that there may be etymologizing strands in the critical discourse of De Lingua Latina itself which fall well short of our category of "explicit etymology'.

Hence my supplementary question for this brief section of my paper. How are the limits of etymologizing shifted if Varro himself, our best benchmark of "explicit etymologizing", is also himself an aficionado of implicit etymologizing, nonetymological paronomasia, and even (perhaps) of flippant verbal puns and jokes (whether etymological or not)? I will do no more than set out a couple of lines of inquiry.

My first interrogative gesture is to reprint part of Varro's treatment of the Venus nexus (already discussed in Section 1) - and to reprint it twice (LL 5.61-2):25

... et horum vinctionis vis Venus. hinc comicus: "huic victrix Venus, videsne haec?" non quod vincere velit Venus, sed vincire. ipsa Victoria $a b$ eo quod superati vinciuntur

... et horum vinctionis vis Venus. hinc comicus: "huic victrix Venus, videsne haec?" non quod vincere velit Venus, sed vincire. ipsa Victoria ab eo quod superati vinciuntur

The top quotation gives typographical emphasis to words which can reasonably be argued from this passage and from corroborative ancient evidence elsewhere to be involved in a discussion about etymological linkage; the repeat quotation below emphasizes patterns - "mere" patterns - of alliteration and assonance. What is to be made of this? Well, without pressing the implications as far as Frederick Ahl, for one, would wish to press them, ${ }^{26}$ one can at least use a pairing like this to observe that it is characteristic of Varro to generate a kind of atmosphere of sympathetic paronomasia when he etymologizes.

My second interrogative gesture is to set out a sampling of passages from various points in Book 5 of De Lingua Latina, in each of which an argument can be made, with near-certainty in the first case but with increasing equivocation in the other three, that an explicit etymologizing set (underlined) is enriched or diversified by an implicitly etymologizing component (in bold italics). Modern commentators and translators have tended to disagree in their attributions of etymological intent to the words concerned something which may be instructive in itself. I begin with a particular crux in the passage just quoted.

\section{(a) The force of fire and water (LL 5.61)}

et mas ignis..., aqua femina..., et horum vinctionis vis Venus

and fire is male..., and water is female..., and the force that brings their vinctio

"binding" is Venus "Love'.

41 Is an etymologizing link intended here between vis and Venus? ${ }^{27}$ Not for Roland Kent, Varro's Loeb editor, whose interpretative translation of the crucial phrase (quoted above) leaves vis unflagged, as an etymologically inert term in the sentence. But Jean Collart's 1954 edition tells a different story: “...comme, pour Varron, vis et vinctio sont de la meme famille (cf. GRF fr. 265, p. 284), ${ }^{28}$ l'expression constitue une figura etymologica." As it happens, two chapters later, Varro juxtaposes vis and Venus again ( $L L$ 5.63): 
poetae de caelo quod semen igneum cecidisse dicunt in mare ac natam « e spumes» Venerem, coniunctione ignis et humoris, quam habent vim significant esse Veneris. a qua vi natis dicta vita...

The poets, in that they say that the fiery seed fell from the sky into the sea and Venus (i.e. Aphro-dite) was born "from the foam-masses", through the conjunction of fire and moisture, are indicating that the vis "force" which they have is that of Venus. Those born of this vis have what is called vita "life" ... the near-adjacent passages do seem mutually corroborative. But note how Collart's use of the term "figura etymologica" has left Varro in a grey area in terms of the larger question under discussion here. Is the link between vis and Venus explicit or implicit? Implicit in the first passage (5.61) but explicit in the second (5.63)? How meaningful is an explicit/implicit distinction where Varro's etymologizing is concerned? If we have taken this issue on board, we may now be ready for Frederick Ahl's gloss on the last phrase in the 5.63 passage above, a qua vi natis....29

"A QUA VI - the source of force contains AQUA, water."

Not as wild as it looks; ${ }^{30}$ but let us save Ahl for later.

\section{(b) Home cooking (LL 5.127)}

vas ubi coquebantcibum, ab eo caccabum appellarunt

The vessel in which they coquebant "cooked" their food, from that they called a caccabus.

Is cibum involved in the etymology explicitly or implicitly - or not at all? Collart's interpretative translation registers the word, Kent's (quoted above) does not. ${ }^{31}$ In other words, is this or is this not a two-word etymology of the type "quod unaiuvat cum Iove, Iuno'? 32

\section{(c) Public works (LL 5.158)}

Clivos Publicius ab aedilibus plebei Publicis qui eum publice aedificarunt The Clivus Publicius "Publician Incline", from the members of the Publician gens who as plebeian aediles constructed it by state authority.

Does publice participate as an etymologizing component, as a joke, or neither... or both? The modern commentators ignore it; ${ }^{33}$ but when this street-name aition is replayed a couple of generations later in Ovid's Fasti, the idea of publica cura is quite clearly etymologized into the tale of this historic intervention by the Publicii (5.285-94):

vindice servabat nullo sua publica volgus;

iamque in privato pascere inertis erat.

plebis ad aediles perducta licentia talis

Publicios: animus defuit ante viris.

rem populus recipit, multam subiere nocentes:

vindicibus laudi publica cura fuit.

parte locant clivum, qui tunc erat ardua rupes:

utile nunc iter est, Publiciumque vocant.

Common folk had no champion to protect their share in public property (sua publica); and at length it was deemed the sign of a poor spirit in a man to graze his cattle on his own land. Such licence was brought to the notice of the plebeian aediles, the Publicii; till then men's hearts had failed them. The case was tried before the people: the guilty 
were fined: the champions were praised for their public spirit (publica cura)... With part of the fine they contracted for making a way up the slope, which then was a steep rock: now it is a serviceable road, and they call it the Publician road.

\section{(d) Potential well-springs (LL 5.24-5)}

is [i.e. humor] si quamvis deorsum in terra, unde sumi pote, puteus; nisi potius quod

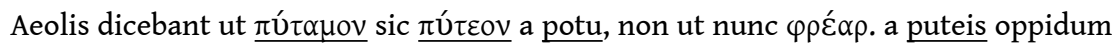
ut Puteoli, quod incircum eum locum aquae frigidae et caldae multae, nisi a putorepotius, quod putidus odoribus saepe ex sulphure et alumine. extra oppida a puteisputiculi, quod ibi in puteis obruebantur homines, nisi potius, ut Aelius scribit, Puticuli quod putescebant ibi cadavera proiecta, qui locus publicus ultra Esquilias If this moisture is in the ground no matter how far down, in a place from which it pote "can potentially" be taken, it is a puteus "well-pit'; unless rather it relates to what the Aeolians used to call $\pi \dot{v} \tau \varepsilon \circ \varsigma$ "drinkable", like $\pi \dot{\tau} \tau \alpha \mu \circ \varsigma^{\prime}$ "river", from potus "act of drinking" - and not $\varphi \rho \varepsilon ́ \alpha \rho$ "well" as they call it now. ${ }^{34}$ From putei "wells" comes such a town-name as Puteoli, because around this place there are many hot and cold spring-waters; unless rather from putor "stench", because the place is often putidus "stinking" with smells of sulphur and alum. Outside the towns there are puticuli "little pits", named from putei "pits", because there the people used to be buried in putei "pits'; unless rather, as Aelius writes, the Puticuli are so called because the corpses which had been thrown out putescebant "used to rot" there, in the public burial-place which is beyond the Esquiline.

Finally, what happens when, three times in the above passage, potius, "rather", a common expository prop in Varro's critical prose, is drawn assonantly into an etymological chain of "well" words... in which it may just conceivably be felt to have a more than assonantal interest? That is, what are we to make of the opening sentence's assonantal juxtaposition of puteus with the merely expository nisi potius - given that puteus has just been explicitly etymologized from unde sumi pote? Carelessness? A joke? If so, an etymologizing joke, or just paronomasia? Is such a distinction really secure in an instance like this? And if we register the (merely) assonantal participation of possunt in a related etymologizing pattern later in Varro's fifth book (LL 5.122),

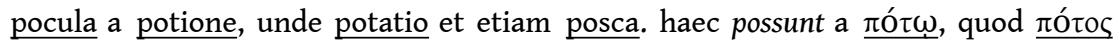
potio Graece

pocula "drinking-cups", from potio "draught", whence potatio "drinking bout" and

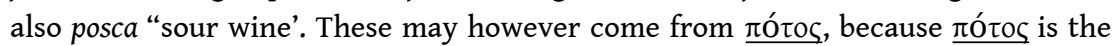
Greek for potio

does this tell for or against an etymological reading of pote/puteus/potius at 5.24-5? But, before we get bogged down in minutiae, it is time to attempt a more spacious overview.

\section{The universe of the word}

Between one thing and another, the name of Venus seems variously to be linked in ancient etymologizing contexts with vincire, vincere, vis, venire and vendere, ${ }^{35}$ as well as with its true cognates venia, venerari and venenum. The very proliferation of links up for discussion makes it tempting to look beneath the surface of ancient theorizations of etymology, and to see immanent in Roman etymologizing a potential for words to fall into patterns of endless deferral, with Venus and her cognates all containing traces of each other and of other words too, and finding meaning through a continual slippage between these shifting areas of possibility. This is a fruitful perspective. However, 
although I do think that the proliferation of etymological possibility can indeed be used to apply this kind of deconstructivepressure to Varro's (or anyone else's) extant attempts to control the name of Venus, there is another way of looking at it - one perhaps more complicit with Varro's own view of things.

Let me instead here sketch a view of the proliferation of etymologies as symptomatic of a kind of totalizing grammar, a grammar which finds in the negotiations between Venus, vincire, vincere,etc. not a movement towards infinite deferral and unfixity of meaning, but a movement towards plenitude and perfection of meaning. This is a way of looking at things which was familiar to many medieval and Renaissance readers of ancient texts, but whose importance for our reading of classical Latin literature is only now up for re-exploration (under the influence of reception studies, and in line with a new interest in Roman systems of knowledge) after long neglect. For word-plays both divine and secular, on this approach, an etymologizing pattern can be thought to build up a series of explanatory connexions structuring the world (etymology working as aetiology, and ultimately as cosmology) - whether overtly or at the level of submerged cultural connection.

It is worth dwelling on the idea of divine word-play for a page or two. The etymologizing juxtapositions discussed in Section 1 are all implicated in the naming of a god. A few of the poetic ones, but not all of them, might be termed "cletic", in that they involve actual invocations of that god. For divine word-plays in general the characteristic "grammar" of etymology may usefully be thought of, I submit, as a kind of religious discourse, more specifically as a kind of catechism: to invoke my totalizing perspective again, it may be thought of as a manifestation of the cover-all-bases "bywhatsoever-name-you-wish-to-be-called" mind-set of Greco-Roman religion sometimes overtly and explicitly so, more often at a deeper, subliminal level. To negotiate with the divine, to comprehend the divine, to control the divine, one must embrace the divine in its totality. In the case of Venus our "etymological catechism" operates to ask and answer a series of questions.

Who is the binder?

Who is the conqueror?

Who has the force?

Who comes to all?

Who is the granter of indulgence?

Whom do we venerate?

Who is the dispenser of drugs and charms?

To all of these questions the response is "Venus'; all these issues concerning the divine are negotiated within etymologizing patterns like those treated in my first section. My suggestion would be that the name-games which (say) the love-poet plays with Venus, though explicable at other levels in terms of wit, thematic shaping, and scholarly virtuosity, function at the level of the sacred as expressions of a subliminal habit of theological thinking - call it quasi-liturgical meditation, call it etymological catechism, call it the totalizing desire to comprehend the divine by naming all its names.

In an acute discussion of Ovid's Fasti, John F. Miller has indeed come up with something very like this to describe a pattern of explanation in that poem which involves a distinctive intersection between didactic and hymnic modes - well exemplified in the poet's four explanations of the cult title Capta given to the goddess Minerva in Fast. 3.837-48: 
parva licet videas Captae delubra Minervae,

quae dea natali coepit habere suo.

nominis in dubio causa est. capitale vocamus

ingenium sollers: ingeniosa dea est.

an quia de capitis fertur sine matre paterni

vertice cum clipeo prosiluisse suo?

an quia perdomitis ad nos captiva Faliscis

venit? et hoc signo littera prisca docet.

an quod habet legem, capitis quae pendere poenas

ex illo iubeat furta recepta loco?

a quacumque trahis ratione vocabula, Pallas, pro ducibus nostris aegida semper habe

You may see the small shrine of Minerva Capta, which the goddess owned for the first time upon her birthday. The origin of the name is doubtful. We call ingenuity “ capital'; the goddess herself is ingenious. Did she get the name Capta because she is said to have leaped forth motherless with her shield from the crown of her father's head (caput)? Or because she came to us as a captiva at the conquest of Falerii? An ancient inscription tells us this with its sign. Or was it because she has a law which ordains capital punishment for receiving objects stolen from that place? From whatsoever source you derive the title, O Pallas, always hold your aegis before our leaders.

51 In the etiquette of this passage (see esp. my italics in the penultimate line 847), Ovid exploits both the explanatory power and the liturgical potential of divine etymology in an unusually deliberate way. As Miller puts it, aetiological and aretalogical formulae here converge: the etymologist is at the same time, quite overtly, a hymnist. ${ }^{36}$

What I should like to do is to generalize Miller's point outwards to illuminate divine word-play at large. In many of the Venusian etymologies in my first section, the religious element is not something to be thought of at the level of conscious authorial or readerly intention, but more at the level (if the phrase doesn't sound too much like obfuscation) of the culture's mental infrastructure; such an approach to the issue invites us to focus (like anthropologists) on how a culture speaks though an individual rather than vice versa. That is to say, a grammarian like Varro may not mean on a given occasion to explore the religious dimensions of Venus, still less to celebrate, or hymn Venus, or to control or negotiate with her, when he etymologizes her name; but at some level his Venusian philology, like the Venusian puns of Augustan amatory elegy, is underpinned and energized by a cultural programme of religious exploration - even if the grammarian's bookish curiosity and the poet's witty conceit seem to have less to do with that programme than does the overtly liturgical discourse of the hymnist.

I adumbrate this approach because, given what Tom Habinek referred to in 1992 as the dominant aestheticizing tendency in Roman literary studies, the kinds of dimension with which I am concerned here - religious, cosmic, totalizing - have tended not to be emphasized when etymology is discussed by poetic Latinists. ${ }^{37}$ Instead the interpretative choices for dealing with etymology have been envisaged either as falling within the ambit of scholarly doctrina, of which etymology is indeed one of the trademarks, or as a matter of aesthetics internal and specific to a single literary artefact, a well-wrought urn of verbal wit.

These are important interpretative emphases and have brought us a long way in almost thirty years of sustained attention to Roman poetic etymologizing; but it does seem to me (and let me emphasize that I am here arguing against deeply engrained aestheticizing habits of my own) that an exclusive emphasis upon scholarly doctrina and 
upon poetic wit can end up selling both the poet and the grammarian a bit short - so that even an attempt as well-intentioned as the following to free the "amusing" poet from the "austere" grammarian does not escape the limitations of the binary opposition thus reconfirmed (Jim McKeown, in his 1987 prolegomena to Ovid's Amores; my emphases): 38

'[Ovid] was not a chalcentric scholar, and did not require even the most informed of his readers to be so either... Whereas an etymological play in the poetry of Callimachus may have the serious and constructive purpose of offering an interpretation of a controversial word, based on his professional philological studies, Ovid's etymologising is based on the instruction which he had received at school. Just as he amused his friends by the exploitation in unfamiliar contexts of sententiae made familiar by the rhetoricians and of well-worn themes for declamation, so he amused them by the vitality with which he inspired the austere scholastic study of etymology. The etymologies themselves will have caused no difficulty; Ovid demanded of his readers only the ingenuity to recognise them in their new surroundings.'

Back when I first read Frederick Ahl's provocative 1985 book on soundplay and wordplay in Ovid's Metamorphoses, I thought that - for all that volume's undoubted perversities $^{39}$ - no critic of Roman poetry would ever be able to talk in quite the same way as before about etymology and etymologizing interpretation in Latin. I was wrong: and it may be no great credit to us that for the most part we carried on our business undisturbed, and left Ahl out on his limb. What Ahl's Metaformations did was to show how word-play defies containment, how it refuses to stay in its box (or in its urn) and threatens to become co-terminous with discourse itself. That is a scary prospect; but we should have stood and faced it, not taken refuge either in easy dismissals of Ahl's book for "going too far", or in selective citation from those moments in Ahl which weren't destabilizing of our own certainties. ${ }^{40}$

Greco-Roman thought is rich in arguments for (and against) the study of words, their derivations and their connexions as a key to making sense of the cosmos - viewed spatially, viewed temporally, viewed theologically. Ever since Hesiod's Theogony, explorations of the universe are bound up with the explanation of words; an inventory of the world is also an inventory of language. A grammatical treatise like Varro's $D e$ Lingua Latina may seem a readier candidate than Hesiod's Theogony for the limiting label of "austere scholasticism" (to use the language of the McKeown quotation above). And yet the generosity of Varro's oeuvre seems to speak against it. Is the author of so many works on secular and divine history, geography, rhetoric, law, philosophy, music, medicine, agriculture, architecture and literary history, the author of 150 books of Menippean satire, really to be dismissed as an exponent of austere scholasticism? Surely not. Varro is a true encyclopaedist of the cosmos; and, like his oeuvre viewed as an oeuvre, De Lingua Latina itself is a sort of universal history, a characteristically Roman encyclopaedia of the orbis and of the urbs.

Those books of De Lingua Latina which we mine most frequently for their wealth of specific etymologies can be argued to bear the strong stamp of the cosmological imagination. Book 5 explores the vocabulary of "place" as it structures the orbis and the urbs; Book 6 explores the vocabulary of 'time'; and (to waive discussion of other vexed aspects of Varronian taxonomy, if that is permissible) what is interesting for the present purpose about this method of organization is that its rationale comes as much from the characteristics of the world as from the characteristics of the word. ${ }^{41}$ 
erning the detailed organization of each book Varro himself professes a certain degree of informality: early in De Lingua Latina 5 he tells us that he will be happy to digress if his pursuit of the connexions of a given word causes him to stray outside the theme of his book (5.13); and in the final chapter he invites us to think that his account has come to a stop at this particular moment because there is no room for any more words on the book-roll (5.184). But, for all that, some strong principles of internal ordering are apparent. Book 5, the Book of Place, after a methodological preamble, begins self-reflexively by etymologizing the word "place" (5.14),

incipiam de locis ab ipsius loci origine

Among places, I shall begin with the origin of the word locus "place" itself

and proceeds thence to explore the primal divisions of "place" within nature (5.16),

loca naturae secundum antiquam divisionem prima duo, terra et caelum, deinde particulatim utriusque multa

The primal places of the universe, according to the ancient division, are two, terra

"earth" and caelum "sky", and then, according to the division into items, there are many places in each

first etymologizing caelum and its cognates, then terra and its cognates. Varro etymologizes caelum, as it turns out, from chaos (5.19-20), thus giving a truly cosmological opening set - and at this point, fittingly enough, he explicitly invokes Hesiod's originary description of Chaos in the Theogony. ${ }^{42}$ Thence his account modulates to the categories of "place" imposed by man upon the earth, dividing the "places" of the terra into Asia and Europe (5.31);43 and Europe into its constituent nations, with an immediate emphasis upon the nations of Italy (5.32); and thence via a taxonomy of types of fields, marked as specifically Roman in its legal-religious accent (5.33),

ut nostri augures publici disserunt, agrorum sunt genera quinque

As our State Augurs set forth, there are five kinds of field

to an extended treatment of the divisions and subdivisions of the city of Rome itself (5.41-56).

59 At this point the fifth book makes a sort of fresh beginning, as Varro moves from explanations of "places" to explanations of "things in places", first immortal and then mortal (5.57 nunc de his quae in locis esse solent immortalia et mortalia expediam); once again this ordering involves a modulation from nature to culture, and from the orbis to the urbs. Hilariously enough, when Varro's inventory brings him to treat of "living things on dry land" (de animalibus in locis terrestribus), subdivided in hierarchical order into "human beings, domestic animals and wild animals", the very first item to make the list is "consul" (5.80). Much more could be said, of course, about the organization of the Varronian Book of Place; the considerable pleasures for the reader are analogous to those of catalogue poetry. However, since my paper is moving towards its close, let me add no more than that the Venus-related etymologies in 5.61-3 - as treated earlier participate fully in the pattern-making of cosmic taxonomy: Venus emerges with new force in this larger perspective as a key binding agent in the universe between heat (which comes from Caelum) and moisture (which comes from Terra) (5.59-60). ${ }^{44}$ Come to that, even the humble puteus of 5.24-5 (Section 2 above) finds its logical place in the book's, and the universe's, grand design.

De Lingua Latina 6, the Book of Time, is hospitable to similar analysis. Again, Varro begins self-reflexively by etymologizing the word tempus (6.3), proceeding thence to explore various time-words associated with the movement of the sun in the heavens (6.4ff.); again, then, the book's cosmological bent is at once apparent. Analogously to Book 5, Book 6 shows a modulation from time-divisions associated with the natural 
order to time-divisions associated with the civic, i.e. the Roman civic order; again, mutatis mutandis, this involves a movement from the immortal to the mortal sphere of reference (6.12):

ad naturale discrimen civilia vocabula dierum accesserunt. dicam prius qui deorum causa, tum qui hominum sunt instituti.

To the division made by nature there have been added the civic names for the days. First I shall give those which have been instituted for the sake of the gods, then those instituted for the sake of men.

61 A brief plug, then, for Varro's encyclopaedia of the word and the world, a work too often read only via index or computer concordance. ${ }^{45}$ And this is where a poet like Ovid may come in again. Most Ovidians instinctively cordon off the etymologizing of the Fasti and Metamorphoses from the etymologizing of De Lingua Latina as poetry from pedantry, as polished art from rude matter. But just for a moment let us use our newly spacious sense of De Lingua Latina to bring the two together: let us read Ovid as like Varro, involved when he plays with words in the same kind of larger project of making sense of the world. ${ }^{46}$ The Fasti and Metamorphoses, like Varro's treatise, are works of cosmic ambition which aim to comprehend the very structure of divine and human history and geography - synchronically, and with the emphasis on the urbs, in the case of the Fasti, diachronically, and with the emphasis on the orbis, in the case of the Metamorphoses ${ }^{47}$ Etymologizing explanation is important in each of Ovid's major poems, in the one making sense of the festivals, in the other bringing out the "logic" of the transformations, through the accumulation of which, respectively, a cosmic picture is put together.

And even in poems in which the cosmic role of etymology is not so overt or systematic, even, say, in the erotic elegies of Ovid and his Augustan contemporaries and predecessors, etymology remains on one level a way of explaining or seeking control over the world - or indeed (since Ovid is in play) of deconstructing such an aspiration to global control. The elegiac etymologies of Venus in Section 1 may fairly be called into service again to illustrate this immanent potential for systematic interpretability in two respects. First, the mobilization of Venus in so many arenas of ancient thought as a prime organizing force within the universe can predispose us to seek some immanent cosmological meaning (cosmological with a large " $C$ ') even in common or garden etymologies of Venus like these. And second, more generally, we can read the elegists" plays in Section 1 as symptomatic of the tendency of all Roman etymologizing to generate little constellations of meaning - cosmology with a small "c", if you like which have their several modest contributions to make to a larger grammar of the word and of the world.

This is a way of looking at things which will often be too deeply submerged in Roman discursive habits to be of much use to a literary critic like myself. However, a better sense of the cultural embedding of etymology will, I think, give us a better sense of what is happening when those cultural habits break surface.

And it may be that the cosmological impulse is more than subliminal in our elegiac etymologies of Venus. The poet-lover in an Augustan collection of Amores lives at the center of an all-consuming erotic world, in which everything offered by life and by literature is obsessively processed into the terms of the elegiac system. ${ }^{48}$ Given such a generic programme, may we not read the proliferating Venusian etymologies in Section 1 as part of a very deliberate poetic project to compass and control all the available names of love, sacred and profane alike, within the narrow universe of elegy - 
a universe in which everything connects, and in which ROMA and AMOR live out the endlessly recursive logic of a cosmic palindrome?

\section{BIBLIOGRAPHY}

Ahl, F. (1985) Metaformations: soundplay and wordplay in Ovid and other classical poets, Ithaca

Cairns, F. (1979) Tibullus: a Hellenistic poet at Rome, Cambridge

Cairns, F. (1996) “Ancient « etymology » and Tibullus: on the classification of « etymologies » and on « etymological markers »", PCPS 42: 24-59

Camps, W.A. (1966) Propertius Elegies Book III, Cambridge

Collart, J. (1954) Varron De Lingua Latina livreV, Paris

Conte, G.B. (1994) Genres and readers, Baltimore (tr. of Generi e lettori, Milan 1991)

Fabre-Serris, J. (1998) Mythologie et littérature à Rome, Lausanne

Fantham, E. (1998) Ovid Fasti Book IV, Cambridge

Fedeli, P. (1985) Properzio: il libro terzo delle Elegie, Bari

Feeney, D.C. (1991) The gods in epic: poets and critics of the classical tradition, Oxford

Friedländer, P. (1941) “The pattern of sound and atomistic theory in Lucretius”, AJP 62: 16-34

Gale, M.R. (1994) Myth and poetry in Lucretius, Cambridge

Günther, H.-C. (1994) “Tibullus ludens”, Eikasmos 5: 251-69

Habinek, T.N. (1992) "Grecian wonders and Roman woe: the Romantic rejection of Rome and its consequences for the study of Roman literature", in K. Galinsky (ed.) The interpretation of Roman poetry: empiricism or hermeneutics?, Frankfurt: 227-42

Habinek, T.N. (1998) The Politics of Latin Literature, Princeton

Hardie, P.R. (1986) Virgil's Aeneid: cosmos and imperium, Oxford

Hardie, P.R. (1993) The epic successors of Virgil: a study in the dynamics of a tradition, Cambridge

Henderson, J. (1987) "Lucan/the word at war", Ramus 16: 122-64 (rewritten in Fighting for Rome, Cambridge 1998: 165-211)

Henderson, J. (forthcoming) Isidore's Creation: Truth from Words, Cambridge

Hinds, S. (1987) “The poetess and the reader: further steps towards Sulpicia", Hermathena 143:

29-46

Hubbard, T.K. (2004-05) “The invention of Sulpicia”, CJ 100: 177-94

Kent, R.G. (1938) Varro De Lingua Latina vol. I (Loeb Classical Library), Cambridge MA

Maltby, R.(1991) A lexicon of ancient Latin etymologies (ARCA 25), Leeds

Maltby, R. (1993) “The limits of etymologising”, Aevum Antiquum 6: 257-75 
Maltby, R. (2002) Tibullus: Elegies (ARCA 41), Cambridge

McKeown, J.C. (1987) Ovid: Amores. VolumeI: text and prolegomena (ARCA 20), Liverpool

Michalopoulos, A. (1998) “Some cases of Propertian etymologising”, PLLS 10: 235-50

Michalopoulos, A. (2001) Ancient etymologies in Ovid's Metamorphoses: a commented lexicon (ARCA 40), Leeds

Miller, J.F. (1992) “The Fasti and Hellenistic didactic: Ovid's variant aetiologies”, Arethusa 25: 11-31

Milnor, K. (2002) “Sulpicia's (corpo)reality: elegy, authorship, and the body in [Tibullus] 3.13", CA 21: $259-82$

Nisbet, R.G.M. and Hubbard, M. (1970) A commentary on Horace Odes Book I, Oxford

O'Hara, J.-J. (1996) True names: Vergil and the Alexandrian tradition of etymological wordplay, Ann Arbor

O'Hara (1996b) “Vergil's best reader? Ovidian commentary on Vergilian etymological wordplay" CJ 91: 255-76

Paschalis, M. (1997) Virgil's Aeneid: semantic relations and proper names, Oxford

Rawson, E. (1985) Intellectual life in the late Roman Republic, London

Ross, D.O. (1987) Virgil's elements: physics and poetry in the Georgics, Princeton

Schiesaro, A. (2002) "Ovid and the professional discourses of scholarship, religion, rhetoric", in

P. Hardie (ed.) The Cambridge companion to Ovid, Cambridge: 62-75

Snyder, J.-M. (1980) Puns and poetry in Lucretius" De Rerum Natura, Amsterdam

Taylor, D.J. (1975) Declinatio: a study of the linguistic theory of Marcus Terentius Varro (Studies in the history of linguistics 2), Amsterdam.

\section{NOTES}

1. An early version was delivered at the University of Texas in 1993. Portions were developed for two conference panels, on Ovidian word-play at the APA (Atlanta 1994; organizers Stephen M. Wheeler and Garth Tissol) and on Latin etymologizing at the Leeds International Latin Seminar (1996). More or less complete versions were delivered in 1997 at Princeton, Columbia, Stanford and Michigan. Belated thanks to all the paper's 1990s readers and audiences. With a few exceptions, English translations of Latin passages are taken or lightly adapted from the Loeb Classical Library.

2. On the etymological connexions of Venus (something of a locus classicus for modern studies of Latin poetic etymologizing), see Maltby (1991) s.v.; then the particular discussions of Cairns (1979) 95, 96, 104; Snyder (1980) 106-7, 114-16, 133-4; Ahl (1985) 205-6, 247; McKeown (1987) 55-7; Maltby (1993) 272-5; Günther (1994) 263-5. Within my paper's period of dormancy, add Paschalis (1997) 44; Michalopoulos (1998) 245-6; Michalopoulos (2001) 169-71.

3. i.e. In order to promote the claims of Venus/vincire, Varro here downplays a Venus/vincere etymology, while implicitly acknowledging its currency: cf. now Michalopoulos (2001) 169 and 171 , adducing in this connexion the contemporary Pompeian temple and cult of Venus victrix in Varro's Rome, inaugurated 55 BCE; cf. Fabre-Serris (1998) 15-16.

4. Kent (1938) ad loc. The footnotes throughout the Loeb edition marking Varro up and down on a modern linguistic scorecard make for amusing reading; but of course a more sympathetic bibliography is available for Varronian linguistics in its ancient intellectual contexts: cf. Taylor 
(1975), esp. x-xi. Good overview at Rawson (1985) 117-31; then O'Hara (1996) 42-50, setting the scene for the discussion of etymology in Latin poetry; and cf. (with particular polemical emphases) Ahl (1985) 17-60.

5. For Lachmann's transposition of 19-20 to precede 15, see e.g. Fedeli (1985) ad loc.; but contrast Camps (1966) ad loc.

6. Fedeli ad loc.; cf. Michalopoulos (1998) 247 on Prop. 3.17.5-6. Ancient discussion of etymology kat" antiphrasin (e.g. lucus quia parum luceat): O'Hara (1996), 66.

7. Cf. Nisbet and Hubbard (1970) ad loc.

8. However note Venus<venia (Serv. Aen. 1.720, quoted in my next subsection) and veneror<venia (Paul. Fest. 374M 517L): Maltby (1991) s.vv.

9. Interestingly, the next and final poem (3.25) contains an overt dismissal of, precisely, mutual binding - but not imaged through Venus/vincire: 3.25.7-8 (addressed to Cynthia) flebo ego discedens, sed fletum iniuria vincit: / tu bene conveniens non sinis ire iugum. "Not imaged through Venus/vincire': but, despite the goddess's verbal absence here, note the presence of her etymological (pseudo-) cognates vincit, conveniens, and indeed, in the poem's and book's very last line (18), eventum formae disce timere tuae: i.e. no more mutual binding; but also "no more victory for Venus victrix; no more Venusian coming together; final exit for the Venus who venit ad omnia ...?"; on the suggestiveness of Venus/venire in etymologizing contexts see my next subsection just below.

10. On the Met., Ahl (1985) and Michalopoulos (2001); on the Aen., O'Hara (1996) (covering Ecl. and Geo. too, and a substantial guide-book to the field at large) and Paschalis (1997). "Contrasting pairs': more on issues of methodological divergence in Section 3 below.

11. Maltby (1993); Cairns (1996); cf. already Cairns (1979) 87-110.

12. Here and below I pick up a train of thought from Hinds (1987). The bibliography on Sulpicia and on Sulpiciana continues to grow: see the list at Maltby (2002) 508; add Milnor (2002) and Hubbard (2004-05).

13. See esp. Maltby (1993) 273-4, with Fantham (1998) on Ov. Fast. 4.13.

14. Snyder (1980) 133-4 with 106-7 and 114-16 (for whom this Venus/venire etymology is supplanted by a Venus/venenum etymology as the poem progresses); Gale (1994) 218. On Venus/ venenum elsewhere cf. O’Hara (1996) 128. Seminal article: Friedländer (1941).

15. More on this formulation in Section 3.

16. So Michalopoulos (2001) 170-1, in a survey ofVenus/vis as a play "well-established in Latin poetry'.

17. Also cf. juxtapositions of vis and Venus in Varro himself at $L L 61$ (quoted earlier) and 63, to be considered in Section 2 below.

18. ... But also quod sine vi femina virgo esse non desinat? On the issue of such assonance, see Section 2 below.

19. Cf. again Hinds (1987), with the more recent bibliography cited in $n .012$ above.

20. i.e. on this reading ipse acquires a secondary emphasis, referring not just back to line 1 but also forward to line 3: you yourself attend Sulpicia's celebration of your cult, i.e. in person; but also (in terms of etymologizing logic), you yourself come, i.e. even though the cletic imperative veni seems more naturally to call for... Venus.

21. 'Belittles': the embarrassment in the envisaged fall of Mars" weaponry in line 4 is compounded by the archly sexual double-entendre available in the word arma.

22. violentus, quia vim infert, as the ancient etymologist would put it (Isid. Orig. 10.279).

23. O'Hara (1996b).

24. Snyder (1980) 106 with 133-4. In contrast, Maltby (1993) 274 makes a cautious case for etymological significance in Venus... venti here (in a discussion of Tib. 1.4.21-2); cf. McKeown (1987) 56. 
25. The text of $L L 5$ excerpts follows Collart (1954) throughout, with some simplification of layout to make room for my own typographical needs. Despite the general susceptibility of the text of $L L$ to corruption, no obvious uncertainties affect the particular points at issue in this section.

26. Cf. Ahl (1985), esp. 35-40 on the idea of "syllabic" etymology; see further Section 3 below.

27. Venus/vis has already been canvassed above in another context: Lucretius DRN 1.12-13 and 4.1113-14 with Aug. Civ. Dei 6.9, and my n.016.

28. Varro GRF (Funaioli) fr. 265, p.284 (= Aug. dialect. 6.12) scrutatur, ipsum vincire unde dictum sit; dicemus a vi.

29. Ahl (1985) 37-8.

30. aqua/a qua: Paul. Fest. 2 aqua dicitur, a qua iuvamur; Cassiod. In psalm. 123,4-51. 98 A. aquam... dixerunt antiqui, a qua sunt omnia; Maltby (1991) s.v. aqua.

31. I infer that Maltby (1991) too excludes cibum from etymological consideration: his citation of LL 5.127 s.v. caccabus is cross-referenced s.v. coquo but not s.v. cibus.

32. Or, indeed, "quod una iuvat cum Iove, Iuno", with the famous etymology for Juno (Varr. LL 5.67) shading into a three-worder? Cf. the one-word version at Cic. N.D. 2.66 sed Iunonem a iuvando credo nominatam.

33. i.e. no etymologizing role for the adverb flagged by Kent (trans. above) or Collart, no crossreference s.v. publicus in Maltby (1991).

34. My translation of Varro's elliptical first sentence here takes its cue from the version of Collart; cf. his explanatory note ad loc.

35. On Venus/vendere (not treated above) see Maltby (1993) 274-5, citing Tib. 1.4.59 and Ov. Am. 1.10.29-34.

36. Miller (1992) 24-7.

37. Habinek (1992) 227-8. (Later modification of his charge in acknowledgement of changing emphases in the field: Habinek (1998) 8-9.) This and the following paragraph, written almost a decade ago, speak in the first instance to the general critical anxieties of a mid 1990s Latinist. However I think they still have relevance in the particular ambit of Roman etymological studies: let them stand.

38. McKeown (1987) 61-2.

39. What makes Ahl (1985) perverse is not so much the implausibility of any particular word- or syllable- play but more the fact that (after an initial scene-setting chapter) the main body of its discussion largely eschews the kinds of corroborative and contextual material (loci in the ancient etymologists, parallels in other poems) which could win the wider acquiescence of students of poetic etymologizing - even where such material is readily available. (Hence the cue for Michalopoulos (2001), organized along more orthodox lines.)

40. Although very different in its approach, Michael Paschalis" study of proper names in the Aeneid poses some analogous challenges in its mould-breaking account of Virgilian etymologizing; see esp. Paschalis (1997) 2-3. (Cf. n.010 above.)

41. Argument from the world to the word: see e.g. LL 5.13 quare quod quattuor genera prima rerum, totidem verborum "Therefore because the primal classes of things are four in number, so many are the primal classes of words'.

42. Cf. Ahl (1985) 24-5.

43. Ancient traditions of bipartite division into Asia and Europe versus tripartite division into Asia, Europe and Africa: Collart (1954) on LL 5.16.

44. The available association of 5.62's Venus victrix with the landmark Pompeian shrine of that name (n.03 above) adds an implicit Roman dimension at this point too: see esp. Fabre-Serris (1998) 15-16.

45. Significantly, the quadripartite division operative in $L L 5$ and 6 (places and things in places, times and things done in times, 5.10; i.e. locus et corpus, tempus et actio, 5.12) corresponds quite closely to a quadripartite division into "who, where, when, what" operative (on the report of 
Augustine) in Varro's lost Antiquitates (with a switch in the order of the first two categories): Civ. Dei 6.3 intendit enim qui agant, ubi agant, quando agant, quid agant; on this see Taylor (1975) 67-70.

46. When I first wrote this paragraph, ground-breaking work on various fronts had just recently directed new attention to the strong cosmological drive of much Roman poetry (esp. Hardie (1986) and Ross (1987) on Virgil, Henderson (1987) on Lucan, Feeney (1991) and Hardie (1993) on the whole epic tradition); more often than not the cosmologies under discussion in these studies included significant elements of etymology.

47. Interest in this kind of Ovidian "encyclopaedism" in the Fasti and Metamorphoses has continued to grow in recent years: see, with bibliography, Schiesaro (2002).

48. Cf. Conte (1994) 35-65 at36-8.

\section{ABSTRACTS}

This paper on Roman etymologizing and etymological word-play was orginally conceived in the 1990s as a response to Robert Maltby's Lexicon of Ancient Latin Etymologies.Section 1 offers a snap-shot of etymological word-play inaction in Augustan elegy; the focus is on plays associatedwith the name of Venus, in Propertius and in the poems of theCorpus Tibullianum associated with Sulpicia. Section 2 turnsfrom the poet to the grammarian, and briefly considers the language used to expound etymologies in Varro's De Lingua Latina. Section 3 employs readings of Varro and of Ovid to adumbrate larger epistemological issues connected with etymology and etymological word-play in its Roman cultural contexts, and in modern critical practice.

\section{INDEX}

Mots-clés: De Lingua Latina, etymological word-play, etymology, Ovid, Propertius, Sulpicia, Varro, Venus

\section{AUTHOR}

\section{STEPHEN HINDS}

University of Washington, Seattle 